\title{
Democratic hypocrisy: Polarized citizens support democracy-eroding behavior when their own party is in power
}

\author{
Jennifer McCoy (Georgia State University),jmccoy@gsu.edu \\ Gabor Simonovits (Central European University), simonovitsg@ceu.edu \\ Levente Littvay (Central European University), littvayl@ceu.edu
}

\begin{abstract}
With a decade of democratic backsliding in the world and the polarization-driven institutional erosion in the US, people's support for democracy-eroding political leaders is receiving much overdue attention. But existing studies have a difficulty disentangling contextual effects (such as who is in power at the time of the survey) from individual differences (like which party one supports and how much). We propose a novel survey experimental design to strip away the political context through hypothetical scenarios. This allows us to gauge the public's democratic hypocrisy: how much a citizen's approval of eroding democratic norms and institutions depends on how much one likes the party in power. Findings suggest that while Republicans are more approving of policies that erode democratic norms and institutions no matter which party is in power at a given time, both Democrats and Republicans engage in democratic hypocrisy, supporting a change in democratic practices when it will enhance their party's advantage. The magnitude of that effect is stronger for individuals with stronger partisan attachment.
\end{abstract}

Prepared for the American Political Science Convention, Sept 10-14, 2020.

Panel on Seeking Solutions to Polarization: the U.S. in Comparative Perspective

Thu, September 10, 2:00 to 3:30pm MDT (4:00 to 5:30pm EDT) 


\section{Introduction}

Anxiety about democracy is widespread globally as elected governments themselves undermine basic tenets of democracy in their quest to remain in power or to achieve fundamental political or social change. The $21^{\text {st }}$ century threat to democracy is thus a form of gradual democratic erosion from within, carried out by leaders concentrating power with the support of voters (Bermeo 2016; Diamond and Plattner 2015; Waldner and Lust 2018). Puzzlingly, in many countries such erosion has taken place even in the face of generally high support for democracy. Thus, the debate that this paper seeks to contribute to centers on the question of why citizens supportive of democracy, in general, tolerate or even encourage the erosion of existing democratic norms by their elected leaders, rather than serve as a check on undemocratic political behavior (Graham and Svolik 2020).

The account that we test posits that voters condition their support for specific policies that potentially undermine democratic norms based on whether their own party is in power. We view support for anti-democratic policy as an extreme consequence of partisan polarization that leads citizens to support the party in power in its use of democracy-eroding measures to consolidate its power, and thus pursue their preferred policies. We call this phenomenon democratic hypocrisy or the notion that support for democratic norms are conditioned on one's preferences for the office holder, i.e. whether one's co-partisans are in power or in the opposition. We further argue that this tendency is exacerbated by affective partisan polarization, as partisan social identity increases (Huddy, Mason and Aaroe 2015) and distrust and perceptions of threat of the out-party grows (McCoy, Rahman and Somer 2018).

One issue with testing this account is that in any given point in time, the party in power is fixed. For instance, while recent observational studies have found a higher proclivity of conservatives to support policies undermining democratic institutions (Drutman, Diamond, and Goldman 2018a; Stolle et al 2019; and Lanford, McCoy, Bowen, Littvay 2020), because these 
changes would favor their party or their favored policies it is unclear if these views are driven by individual differences, such as ideology or personality traits, or just the context of who is in power at the time of the study. Elite cues may also shape attitudes of highly partisan individuals; for example, Stolle et al (2019) found that Trump supporters were most willing to support democratic norm violators, possibly influenced by Trump's unbridled espousal of unrestrained executive authority. Thus, using observational survey data it is difficult to distinguish between these mechanisms. Finally, due to the general norm that democracy is good, broad direct questions about support for democracy may also be subject to social desirability bias (Stolle et al 2019; Svolik 2019).

Recent conjoint experimental studies have attempted to tackle these problems by evaluating voter candidate choices based on policies, partisanship and democracy-eroding positions, with mixed results. Carey et al (2018) found little support for dismantling democratic institutions, while in contrast Graham and Svolik (2020) and Stolle et al (2019) found that only a few people are willing to punish actors who endorse rolling back democratic safeguards in polarized contexts. These studies do not assess, however, whether the toleration of democracy-eroding behavior will be stronger when one's in-party is in power. A research design is thus needed that allows us to compare voter reactions to specific democracy-eroding policies when governments of different parties and ideologies are in power in the same national context.

In this study we introduce an experimental approach in which we manipulate - rather than observe - the party in power through a hypothetical situation we present to survey respondents. In a large online survey experiment in the U.S. ( $n=2956$, after exclusions) we ask participants about a series of hypothetical measures that federal or state officials could take that lead to changes in democratic norms and practices to varying degrees across four dimensions of democracy: majority rule, executive constraint (horizontal accountability), civil liberties, and rule of law. In our analysis, we estimate the prevalence of support for these kinds of democratic norm violations across partisan 
groups and using our experiment we assess the role of democratic hypocrisy. Finally, we consider how hyper-partisanship and perceptions of out-party threat, both indicators of severe partisan polarization, account for individual variation in these attitudes.

We report three key findings. First, based on our experiment we report that support for norm-eroding policies is non-trivial - ranging from supporting about $20 \%$ of the policies we considered in the case of the median Democrats to over $30 \%$ for the median Republican. These numbers indicated that a significant fraction of Americans encourage rather than just tolerate these policies. Second, preferences for measures eroding democratic norms are contingent on who is in power: citizens whose party is in power are substantially more likely to support violating existing democratic norms. Third, our analysis also reveals an important role of individual differences: democratic hypocrisy is much more pronounced among those with stronger partisan identities.

These results have important implications for the study of public opinion towards democratic institutions and advance the experimental research on public attitudes toward democratic erosion in several ways. First, compared to Graham and Svolik (2020) who posit that voters view compliance with democratic norms as a valence issue (preferring democracy-complying candidates to democracy-eroding candidates), we view support for democracy as context-dependent and provide evidence that voters often prefer choices that erode existing democratic norms. Second, we show that toleration of democracy-eroding behavior is stronger among those whose in-party is in power. Finally, by varying the context of who is in power, we are able to examine partisan differences in support for democratic norm erosion.

\section{Research design}

The study employs a between-subjects design in which participants are asked to read a scenario about the post-2020 election results that describes who came to control offices such as the President, the Governor, and Congress. Then, given this context, participants are asked questions about some dilemmas tapping their support for democratic principles across four domains: majority 
rule and executive restraint, and liberal values of civil liberties and rule of law. The response choices range from challenging an existing norm within constitutional bounds, such as expanding the Supreme Court or ending the filibuster, to legally ambiguous choices such as protecting presidential immunity for behavior during office, to more egregiously democracy-eroding actions that violate horizontal accountability or civil rights, such as ignoring court decisions perceived as biased or banning protests. The experiment consists of randomly assigning participants to either a condition in which their preferred party won all offices - which we call in-party condition, or a scenario where the participant's party lost - which we call out-party condition. In our analysis we estimate the support for norm eroding policies across these two conditions.

\section{Hypotheses}

Our hypotheses are as follows:

H1: Citizens are more supportive of democratic norm erosion when co-partisans are in power. H2: Higher perceptions of out-group threat and the intensity of partisan identity increase support for democratic norm erosion when co-partisans are in power.

We also conduct exploratory analysis of the party differences between Democrats and Republicans, and item analysis of the democratic norm-erosion index.

\section{Sampling}

We field our survey through Lucid, the largest US marketplace for online panels. Coppock and McClellan (2018) show that treatment effect estimates obtained on Lucid match those obtained on both MTurk and probability samples quite well. For other examples of studies conducted on Lucid, see Flores and Coppock (2018) and Graham (2018). Lucid offers quota-sampling on demographic variables including: age groups, gender, race and region. For this study, we recruited participants who identified or leaned towards one of the major parties, excluding independents. 
We fielded the experiment to a sample of roughly 3000 people (after exclusions) in the context of a multi-investigator project. In order to enhance data quality, we give an attention check to terminate respondents indicative of fraudulent responses: they respond to a "trick question" proposed by Berinsky et al (2014) and they are asked to fill out a text box complying with instructions. If they pass, participants are assigned into one of the treatment groups in a double-blind procedure by the Qualtrics survey platform. Moreover, at the beginning of the survey, we measured party identity with the typical ANES questions, partisan social identity -- intensity of partisan attachment -- with four questions following Huddie et al (2015), and out-group threat questions modeled on the Pew Research Center partisan threat question (See Appendix A). From these we identified the respondents in-party and out-party for the experimental conditions.

\section{Outcome Measures and Experimental Conditions}

Before reading the 16 dichotomous questions presented in the Appendix in the four democracy domains, respondents were randomly assigned to two groups which received scenarios in which either the Democrats or the Republicans swept the 2020 elections. They read this general introduction:

For the next set of questions about the government, imagine this scenario: It's January 2021, and the new president, Senate and Congress and state level officials are being inaugurated following the 2020 elections. The Democrats/Republicans have made a sweep, winning the presidency, the Senate, and the governorship of your state. In a few of the questions below, though, the Republicans/Democrats have won a majority in the Congress (House of Representatives).

The 16 questions were aggregated by taking the share of norm-eroding responses for each respondent for an overall measure of democratic erosion ${ }^{1}$. Party was randomized once for the set and kept the same for all questions to alleviate respondent fatigue.

\footnotetext{
${ }^{1}$ This measure is correlated at $97 \%$ with a measure derived through a 2 parameter IRT model, as declared in our pre-analysis plan. We use this simpler measure for an easier interpretation but our results are identical when using a more nuanced measure.
} 


\section{External Validity}

While the approach offers the flexibility of controlling for partisanship and if a person's preferred party is in power, it is not without flaws. It is presenting a hypothetical scenario, with no true control, which may still be contaminated by divergent political realities of the moment. Still, this approach gets us closest to disentangling the degree to which democratic hypocrisy is present in people's attitudinal evaluations in a mixed political context. For example, studies using conjoint experiments to test voter choice of candidates who do or do not support democracy-eroding policies take place within a time-bound political context, where the voters are aware of the actual party in power.

We also note two attractive features of our design regarding its external validity. First, it is likely that due to social desirability issues many respondents will not feel comfortable in taking anti-democratic positions. As such, our estimates regarding the prevalence of these attitudes can be taken as lower bounds. Second, we are likely to have non-compliance with our treatment, or in other words some survey respondents may find it difficult to imagine scenarios that differ from the status quo (i.e. for Democrats to imagine they hold the presidency). As a result, our treatment effect will also be conservative estimates of the true extent of democratic hypocrisy.

\section{Results}

Following our analysis plan, we compare our measure of support for democratic norm erosion across scenarios where co-partisans vs. the out-party for the respondent is in power. We do so by estimating a simple regression predicting our aggregated measure of democratic erosion score by an indicator for each experimental group. Table 1 reports these baseline findings. Several patterns stand out. First, we see much greater support for norm violation when the respondents' co-partisans are in power, confirming Hypothesis 1. Specifically, in the full sample the observed difference is about $7 \%$, and is similar in magnitude to the mean difference we observe between Democrats and Republicans in each condition. 
Second, and in line with past findings, we also show that Republicans are more norm-eroding than Democrats even in an imaginary context where Republicansare not in power (in contrast to the current one where Republicans have a sizable control over all three government branches and also the majority of state and local governments).

Third, the second and third columns reveal that the (out-party vs in-party in power) treatment effects persist among the supporters of both parties with Republicans exhibiting around $50 \%$ higher differences across the two conditions. In other words, both parties favor democratic norm erosion when their own party is in power, but Republicans intensify their norm erosion more than Democrats when their own party is in power.

Table 1: In-Party / Out-Party in Power Treatment Effects in General and by Party

Sample

\begin{tabular}{lllll}
\hline Condition & All & Democrat & Republican & R-D \\
\hline In-party & 33.6 & 28.5 & 40.3 & 11.7 \\
& {$[0.5]$} & {$[0.7]$} & {$[0.8]$} & {$[1.0]$} \\
\hline Out-party & 26.9 & 23.7 & 31.4 & 7.7 \\
& {$[0.5]$} & {$[0.7]$} & {$[0.8]$} & {$[1.1]$} \\
\hline Treatment effect & 6.7 & 4.9 & 8.8 & 4.0 \\
& {$[0.7]$} & {$[0.9]$} & {$[1.1]$} & {$[1.4]$} \\
\hline $\mathrm{N}$ & 2956 & 1690 & 1266 & 2956
\end{tabular}

Note: Standard Errors in Square Brackets. All differences are significant at the 1\% level. Dependent variable is the percentage of survey items for which a respondent gave a norm-eroding response.

Next we wanted to see how partisan social identity and out-party threat perceptions, as measures of partisan polarization, moderates these findings -- are they differentially related across experimental conditions, as stated in Hypotheses 2. Following our analysis plan, we test this hypothesis by estimating a regression predicting the outcome by an indicator for experimental group interaction with (a) our composite measure of partisan identity strength and (b) or composite measure of threat perception. 
We start our analysis by first visualizing the relationship between our proposed predictors of erosion in each experimental group. Contrary to our expectations, threat is not associated with norm-eroding attitudes when the in-party is in power, though they are negatively related in the condition when the out-party is in power, as might be expected (see Figure 1). That is, people who feel threatened by the out-party want to keep things more democratic when that out-party is in power. $^{2}$

Figure 1. Out-group Threat Moderator with Treatment Group Effect on Democratic Norm-Erosion Index

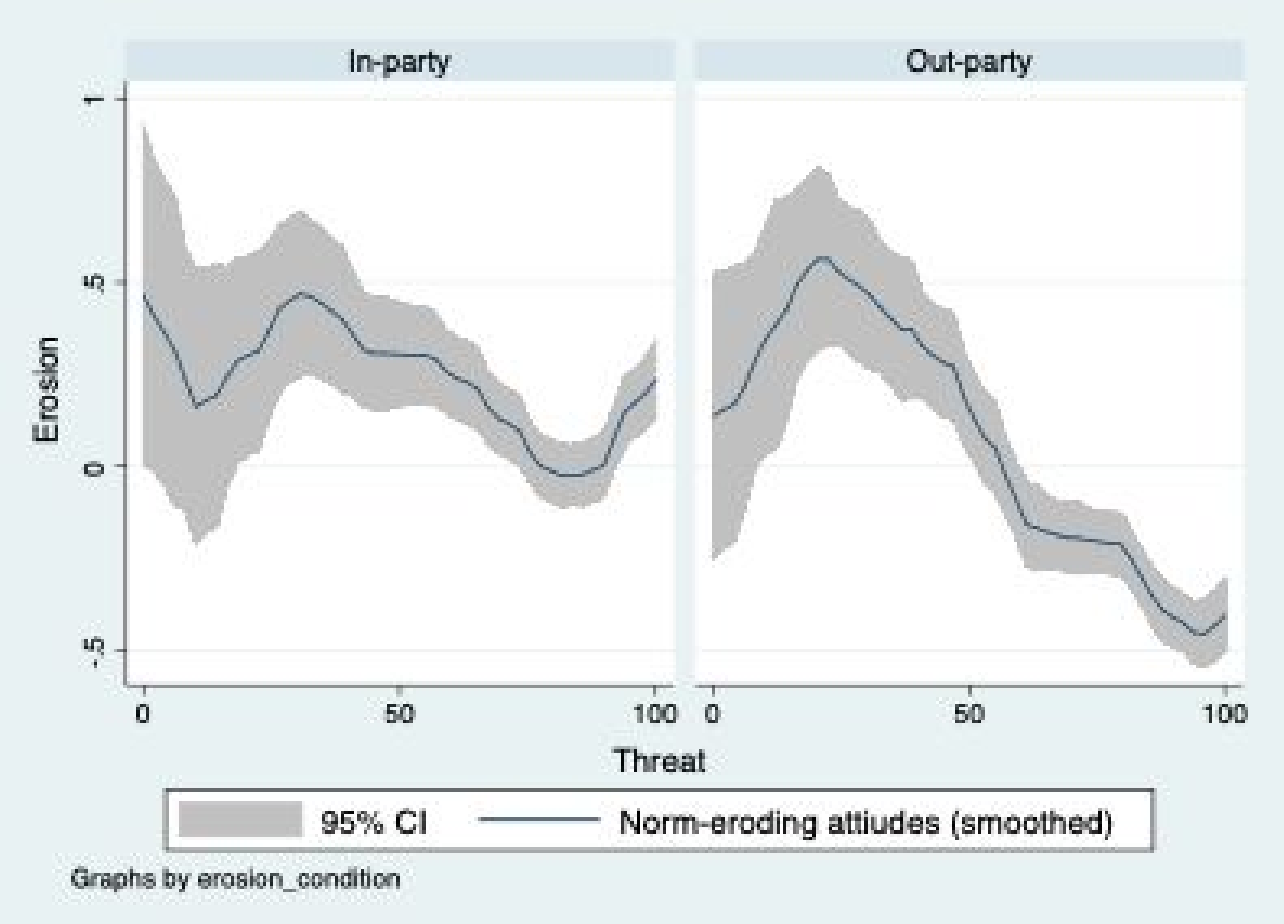

Figure 2 shows that consistent with our expectations, the intensity of partisan identity is positively - and roughly linearly - related to our dependent variable - though we also observe a positive - albeit weaker - relationship in the condition in which the out-party is in power. In other words, the people with the highest partisan attachment support challenges to democratic norms no

${ }^{2}$ One possible explanation for the lack of relationship of threat to norm erosion when the in-party is in power is shown in Appendix B. This table shows that Democrats and Republicans have opposite relationships, with only Republicans showing the expected increase in norm-eroding attitudes in the in-party condition. 
matter who is in power, but they are more democracy-eroding when their own party is in power, as we expected.

Figure 2. Partisan Social Identity Moderator with Treatment Group Effect on Democratic Norm-Erosion Index

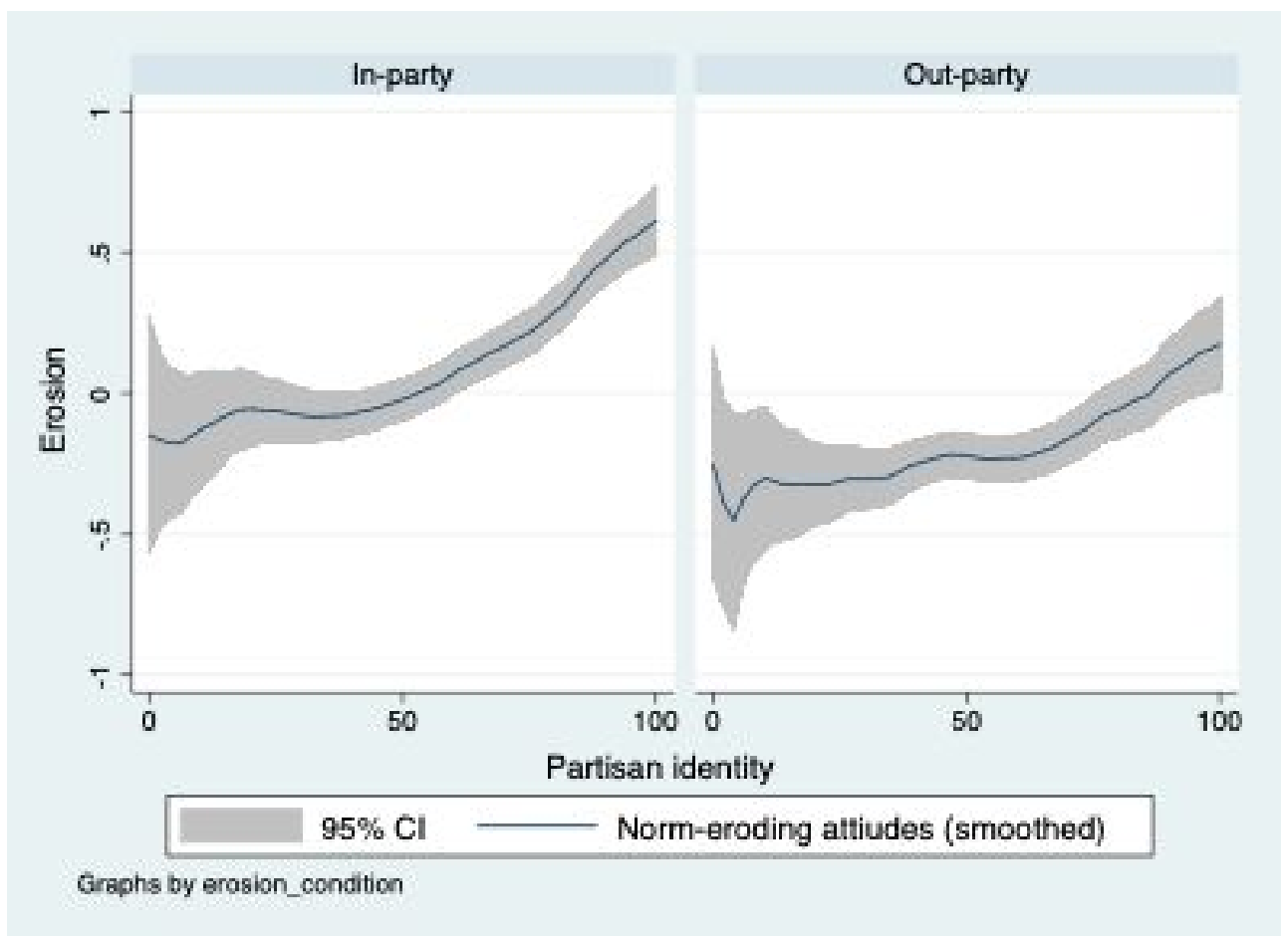

One issue with these analyses is that threat and partisan identity on one hand and norm-eroding attitudes on the other could be related - and indeed differentially related across experimental conditions - for a number of reasons. For a cleaner test of our hypothesis we thus explore variation in democratic hypocrisy as a function of partisan social identity and of out-group threat. In this specification our hypothesis implies that the differences in support for norm eroding policies across conditions with the in-party and out-party in power should increase with partisan social identity and out-group threat. In other words, we would expect that regardless of the baseline support for these policies, individuals who strongly identify as partisans or are most threatened by the other party would condition their support more on who is in power. 
Following Hainmueller et al (2019) we estimate and visualize the treatment effect across the full range of our proposed moderators using a non-parametric procedure In particular, we model our response variable - the proportion of democracy norm-eroding positions an individual took as a flexible function of their partisan identity strength or their out-party threat perceptions and the randomized treatment. Figure 3 shows that those with higher threat and those strongly attached to their party exhibit much stronger treatment effects while those reporting low attachment to their party respond to our dilemmas similarly, whether or not their preferred party is described to be in power.

Figure 3: Conditional effects of in-party (vs out-party) being in power: Partisan Identity and Out-Group Threat.
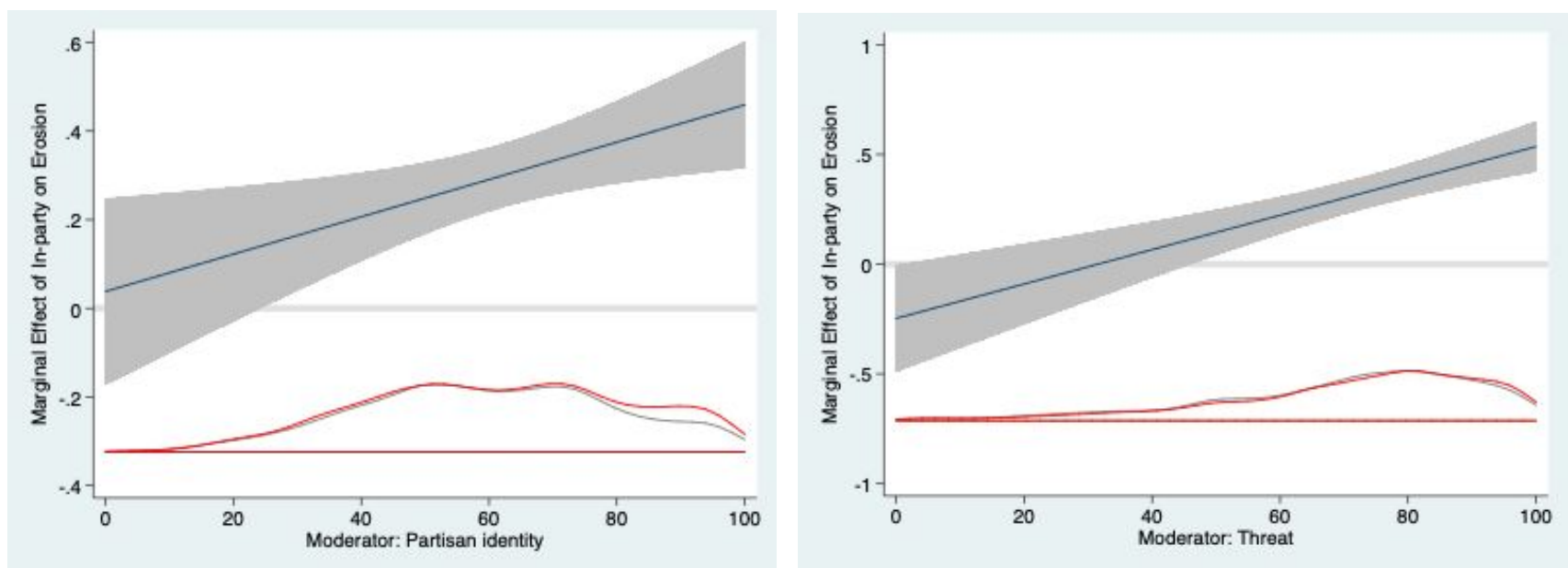

Note: Blue line depicts the conditional treatment effect as a function of the moderator (partisan identity strength) and the grey band is a 95\% confidence interval. The overlapping density estimates (the red and gray lines) visualize the distribution of the moderator across the two treatment groups. 
Finally, we consider heterogeneity in our treatment effects by respondent party and survey items. In Figure 4 we report support for each measure by experimental condition and respondents' party.

Figure 4. Support for democratic norm-erosion by party and experimental condition

\section{Support for antidemocratic policies}

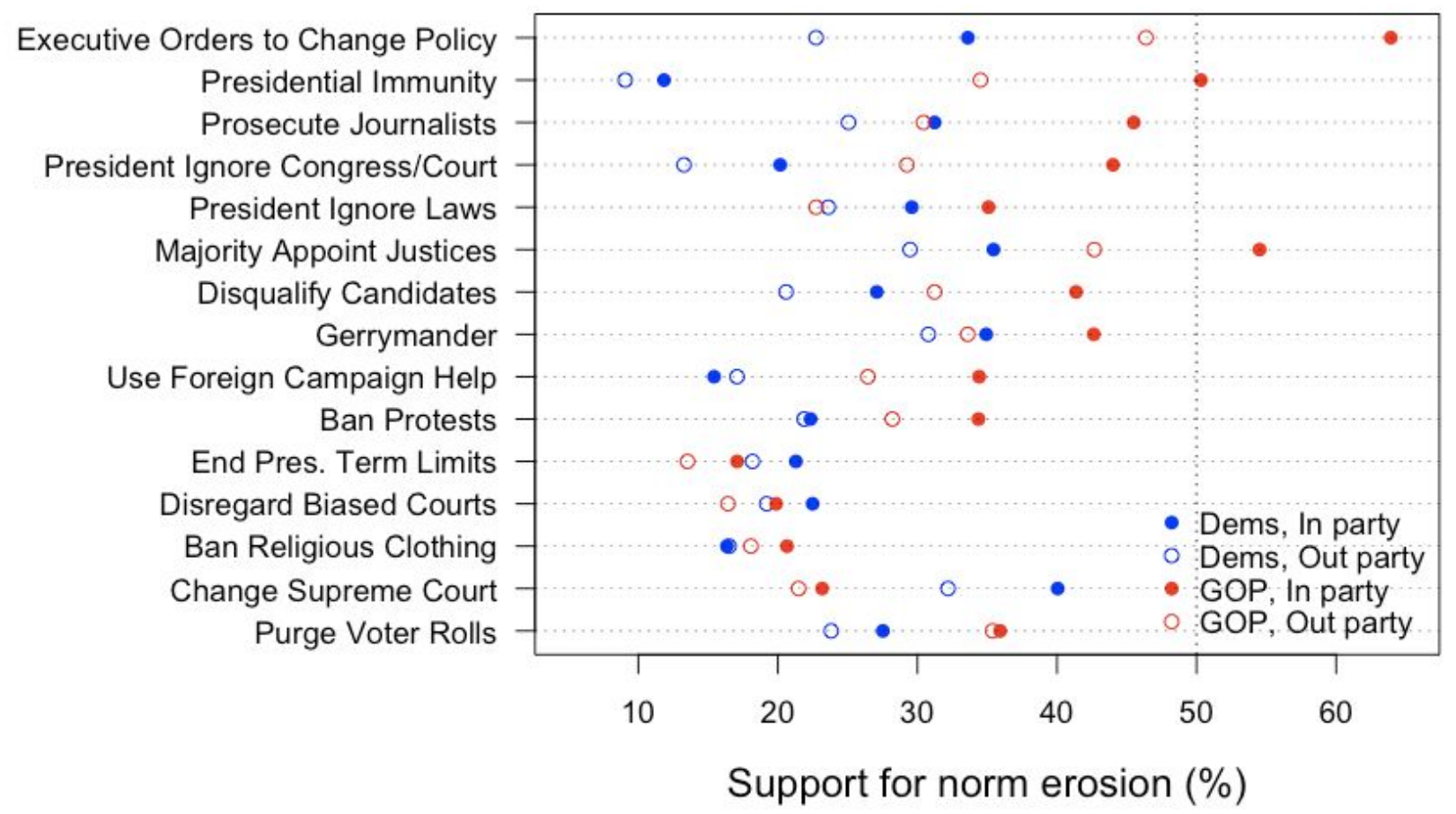

Partisans of both parties showed the most willingness to challenge democratic norms that did not violate the constitution but gave their party more power to act unilaterally when in office: relying on executive orders and removing the filibuster so that the majority party alone could appoint lifetime justices (a norm which in fact was abandoned as of 2019), as well as using gerrymandering to enhance their own partisan advantage when in power. In addition, Republicans were much more inclined to protect presidential immunity, while Democrats were more inclined to change the size of the Supreme Court when in power, reflecting the contentious impeachment trial in 2019-2020 and the growing politicization of Supreme Court appointments. For most of our 
measures of executive aggrandizement and rule of law, Republicans were more inclined to support such measures than Democrats, perhaps reflecting Trump's propensity to expand executive authority and ignore oversight from Congress or the courts.

In terms of protecting civil rights, the most concerning were the responses of both parties to support their own president disqualifying candidates they believed to be disloyal to the country and to support their own governor prosecuting critical journalists reporting with anonymous sources, while Republicans additionally were prepared to use foreign campaign help and to ban protests while in office. The most hopeful results were the relative consensus in terms of both low support (under 25\%) and little change when co-partisans are in power for both parties on three of the more clearly democracy-eroding policies: banning religious clothing, disregarding perceived biased court rulings, and ending presidential term limits.

\section{Discussion}

In line with previous findings, Republicans tolerate democratic norm erosion more than Democrats, even when we strip the political context by giving the hypothetical scenarios. But additionally, both Democrats and Republicans exhibit sizable democratic hypocrisy supporting power-solidifying policies when their preferred parties are in power. Republicans exercise democratic hypocrisy at about a 50\% higher rate than Democrats. These effects are amplified by strong partisan identity.

These findings provide empirical evidence buttressing the concerns that American democratic resilience is fragile, and that public opinion cannot be counted on to stop democratic erosion by leaders or parties intent on expanding their authority and entrenching their partisan advantage. The intense partisan polarization arising from increased partisan social identity appears to be contributing to democratic hypocrisy, when citizens are more likely to challenge democratic norms when their party is in power than when the other party is in power. 
This is the first study to take into account the context of who is in power when assessing citizen attitudes towards democratic erosion. It is possible that the actual political context may still influence responses even under the hypothetical scenario of the out-party gaining power. Therefore, future research should attempt to compare results when the opposition party (in this case, the Democrats) comes to power. Future research could also prime affective polarization and out-party threat to assess their effect on citizen toleration of democratic erosion.

\section{References}

Bermeo, Nancy. 2016. “On Democratic Backsliding.” Journal of Democracy 27 (1): 5-19. https://doi.org/10.1353/jod.2016.0012.

Carey, John, Katherine Clayton, Gretchen Helmke, Brendan Nyhan, Mitchell Sander, Susan Stokes. 2018. "Party, Policy, Democracy and Candidate Choice in U.S. Elections | Bright Line Watch." November 15, 2018. http://brightlinewatch.org/us-elections/.

Diamond, L., and M. F. Plattner. 2015. Democracy in Decline? Johns Hopkins University Press: Baltimore.

Drutman, Lee, Larry Diamond, and Joe Goldman. 2018. “Exploring American Support for Democracy and Authoritarianism.” A Research Report from the Democracy Fund Voter Study Group. 
Graham, Matthew H., and Milan W. Svolik.2020. "Democracy in America? Partisanship, Polarization, and the Robustness of Support for Democracy in the United States." American Political Science Review 114, no. 2 (May ): 392-409. https://doi.org/10.1017/S0003055420000052.

Huddy, Leonie, Lilliana Mason, and Lene Aarøe. 2015. "Expressive Partisanship: Campaign Involvement, Political Emotion, and Partisan Identity." American Political Science Review 109 (1): 1-17. https://doi.org/10.1017/S0003055414000604.

Iyengar, Shanto, Yphtach Lelkes, Matthew Levendusky, Neil Malhotra, and Sean J. Westwood. 2019. "The Origins and Consequences of Affective Polarization in the United States.” Annual Review of Political Science 22 (1): 129-46.

https://doi.org/10.1146/annurev-polisci-051117-073034.

Iyengar, Shanto, Gaurav Sood, and Yphtach Lelkes. 2012. “Affect, Not IdeologyA Social Identity Perspective on Polarization.” Public Opinion Quarterly 76 (3): 405-31. https://doi.org/10.1093/poq/nfs038.

Mason, Lilliana. 2018. Uncivil Agreement: How Politics Became Our Identity. Chicago, Illinois ; London: The University of Chicago Press.

McCoy, Jennifer, Tahmina Rahman, and Murat Somer. 2018. "Polarization and the Global Crisis of Democracy: Common Patterns, Dynamics, and Pernicious Consequences for Democratic Polities." American Behavioral Scientist 62 (1): 16-42. https://doi.org/10.1177/0002764218759576.

Pew Research Center. 2016. "Partisanship and Political Animosity in 2016 | Pew Research Center." June 22, 2016.

http://www.people-press.org/2016/06/22/partisanship-and-political-animosity-in-2016/. 
Stolle, Dietlind, Elisabeth Gidengil, and Olivier Bergeron-Boutin. 2019. "Partisanship and Support for Democratic Backsliding Observational and Experimental Evidence from the United States and Canada." Prepared for Presentation at the Seventh Annual Toronto Political Behavior Workshop at the Munk School of Global Affairs \& Public Policy, University of Toronto.

Svolik, Milan W. 2019. "Polarization versus Democracy." Journal of Democracy 30 (3): 20-32. https://doi.org/10.1353/jod.2019.0039.

Waldner, D., and F. Lust. 2018. "Unwelcome Change: Coming to Terms with Democratic Backsliding." Annual Review of Political Science 21: 93-113.

https://doi.org/10.1146/annurev-polisci-050517-114628.

\section{APPENDIX A}

\section{Pre-treatment Survey Questions}

\section{Partisan Attachment}

How much do you have in common with other [Democrats/Republicans]? [Only the in-party politician/party is displayed] Not At All, A Little, A Moderate Amount, A Lot, A Great Deal

How well does the term [Democrat/Republican] describe you? [Only the in-party politician/party is displayed] Not at all well, Not very well, Somewhat well, Very well, Extremely well

How important is being a [Democrat/Republican] to you? [Only the in-party politician/party is displayed] Not at all important, Not very important, Somewhat important, Very important, Extremely important

When talking about [Democrats/Republicans], how often do you use "we" instead of "they"? [Only the in-party politician/party is displayed] Never, Rarely, Some of the time, Most of the time, All of the time

\section{Threat (5 point Agree-Disagree Scale)}


When you look at Democrat/Republican politicians, would you agree that their policies are so misguided they threaten the country's well-being? [Only the out-party politician/party is displayed]

When you look at President Trump/Bernie Sanders, would you agree that his policies are so misguided they threaten the country's well-being? [Only the out-party politician/party is displayed]

When you look at people who don't share your values, would you say the policies they advocate are so misguided they threaten the country's well-being?

\section{Experiment Response Items}

\section{Democratic Values - Majority Rule}

\section{Supreme court}

It is 2021, and the [Democrats/Republicans] have captured both the Senate and the presidency. They have the opportunity to change the Supreme Court. The Constitution does not state how many justices should be on the Supreme Court and in the 19th century the Congress changed the number of justices several times.

Some people say that the majority in the Senate should be able to change the number of justices on the Supreme Court, even if the opposing party disagrees. Others say that the Supreme Court should stay at the current size of nine justices, even if it is imbalanced politically.

What do you think?

Supreme Court size should stay the same

The Senate should be able to change the number of justices

Judges

Now imagine that the [Democrats/Republicans] have won a 51\% majority in the Senate in the 2020 elections. The Constitution does not require it, but the Senate has historically operated on a principle of consulting the minority party to make lifetime judicial appointments like Supreme Court and federal judges. It did this through the filibuster rule requiring $60 \%$ approval to hold a vote on an appointment, although the appointment vote itself only requires a $51 \%$ approval. 
In the last 7 years, though, the Democrats and Republicans have each reduced the filibuster so that currently, the majority party alone is able to appoint lifetime judges, including the Supreme Court. Some people say it is right that the majority party in the Senate should be able to make lifetime judicial appointments with their own 51\% majority, without any bipartisan consensus. Others say that the filibuster should be restored in order to encourage the practice of bipartisan consensus for these appointments.

Which statement do you agree with more?

Allow the majority party to appoint lifetime judges.

Require bipartisan consensus to appoint judges.

\section{Redistricting}

The new [Democrat/Republican] governor and legislature in your state will need to decide how to draw the voting districts after the 2020 census population count. The constitution allows the states to decide who will draw the voting districts.

Some people say that whichever party is in the majority in each state should be able to draw voting district lines that give them additional seats in the legislature. And others say that a non-partisan independent body should draw voting district lines to eliminate advantages to one party or the other.

In your opinion who should be in charge of redistricting?

- The majority party

- An independent commission

\section{Vote suppression}

Imagine that in 2021, the new [Democrat/Republican] governor and legislature in your state will vote on a proposal to remove voters from the voter rolls if they have not voted in the last two elections. This may especially impact inactive [Republicans/Democrats]s who didn't turn out in large numbers in these elections.

Some people say that the state government should clean up the voter rolls by removing voters if they have not voted in the last two elections. Others say that it is a constitutional right to vote and voter names should not be removed once they have registered.

In this scenario, what do you think should happen with the names of those who do not vote regularly? 
- They should be removed from the roll

- They should stay on the roll

\section{Democratic Values - Executive constraint}

\section{Executive orders}

Imagine that it's 2021 and the [Democrats/Republicans] have won the presidency, but not the Congress. Legally, the president has authority to write executive orders to enforce laws and implement policy. These orders may be overturned by the courts if they are determined to violate existing law, or if the Congress votes against them.

Some people say that the president should be able to change important national policy, like healthcare or immigration, by using the powers of executive order when Congress refuses to cooperate. Others say that only the Congress should be able to make major changes to national policy.

In this scenario, should the president be able to make major changes to policy without the consent of Congress?

- Yes, the president should

. No, the president should not

\section{Unilateral action 1}

Again, imagine that it's 2021 and the [Democrats/Republicans] have won the presidency, but not the Congress. The president wants to carry out his/her mandate from the people for change, but is hampered by the Congress controlled by the [Republicans/Democrats]s who refuse to pass new laws.

Some people say that the president should do what the people want even if it goes against existing laws. Others say that the president should follow the law even if it's not what the people want.

In this 2021 scenario, in your opinion, should the president do what the people want even if it goes against the law?

- President should do what people want

- President should follow the law

\section{Unilateral action 2}


It's 2021 and the [Democrats/Republicans] have won the presidency, but not the Congress in the 2020 elections. The new president wants to carry out rapid change to address the urgent needs of the country. Some people say that our president should have the necessary power to act in favor of the national interest, even if Congress or the Supreme Court opposes it. Others say that the president should get the agreement first from Congress and the Supreme Court before making major changes.

In this scenario, please indicate which of the following statements you most agree with.

- The President should have the power to act alone

- President should get agreement of Congress and Supreme Court

\section{Presidential term limits}

Now imagine that it's 2021, and the [Democrats/Republicans] have won the presidency, the Senate AND Congress. They make a proposal to remove any term limits and allow the president to be reelected more times than the current two-term rule.

Some people say that term limits are undemocratic because they do not allow the people to keep voting for a popular president. Others say that term limits are needed to make sure no single person gains too much power over the country.

On the whole, are you in favor or opposed to presidential term limits?

Favor presidential term limits

Oppose presidential term limits

Democratic norms - Civil Rights

\section{Protest}

Imagine that the [Democrats/Republicans] have won the governorship in your state in the 2020 elections and must decide how to handle growing protests in your state. In this scenario, do you think that the governor should be allowed to ban protests, or is it more important to defend the right to protest, even by extremists?

Governor should NOT be allowed to ban protests

Governor should be allowed to ban protests 
The [Democrats/Republicans] have won the governorship in your state in the 2020 elections. The new governor is pushing the authorities to prosecute a journalist who accused the governor of misconduct without revealing sources. In this scenario, should the governor have the right to prosecute this journalist?

- Governor should have the right to prosecute

- Governor should NOT have the right to prosecute

\section{Disqualify candidates}

It's 2021 and the [Democrats/Republicans] have won the presidential election. To protect the country, the president now wants to disqualify candidates who are disloyal to the country from running for office. In this scenario, should the president have the power to disqualify specific candidates the president believes to be disloyal to the country?

- President should have the right to disqualify candidates

- President should NOT have the right to disqualify candidates

\section{Ban Religious Clothing}

The [Democrats/Republicans] have won the governor's election in your state in the 2020 elections. The new governor wants to ban people from wearing anything that expresses religious affiliation in public. In your opinion, should the governor have the right to ban people from wearing things that express religious affiliation in public?

Yes, governor should have that right

No, governor should not have that right

\section{Democratic norms - Rule of law}

Disregard Biased Courts

Imagine that it's 2021 and the [Democrats/Republicans] have won the presidency and the majority in Congress and the newly-elected [Democrats/Republicans] are questioning the impartiality of the courts.

Some people say that elected officials must obey the courts even when they think that the decisions are politically biased against the president's party, while others 
argue that elected officials should not be bound by court decisions they regard as biased.

What do you think?

- Court rulings should always be obeyed

- Some court rulings should be disregarded

\section{Foreign interference}

Imagine that the [Democrats/Republicans] have just won the 2020 presidential election, but there are many allegations of foreign help to the new president's campaign.

Some people say that candidates should be able to use any information about their opponents during the campaign, even if it comes from outside the country and is difficult to verify. Others say that the new Congress should pass a law requiring all candidates to report to the FBI any foreign offers of help, such as dirty information on their opponents.

In your view, should foreign information be used in campaigns or reported to the FBI?

- It should be used in the campaign

. It should be reported to the FBI

\section{Accept election results}

It's 2021 and the [Democrats/Republicans] have just won a bare majority in Congress, but their opponents claim the election was so influenced by illegitimate campaign contributions and problems with the voter registration lists that the [Democrats/Republicans] didn't really win a majority.

Some people say that political candidates should respect election results even if they believe they lost an election due to unfair practices. Others say that they should refuse to accept results that they believe are due to unfair practices, even if they can't prove it conclusively.

What do you think candidates should do when they think they lost due to unfair practices?

Accept the results

Refuse to accept the results 


\section{Impeachment}

Imagine that it's 2021 and the [Democrats/Republicans] have just won the presidency, but lawsuits have been filed alleging criminal misconduct during the campaign of the new president and a presidential cover up in the first days of the presidency.

Some people say that the president is serving the country and therefore should be immune from prosecution for any action he/she takes as president. Others say that no one is above the law and the president should be investigated in an impeachment inquiry, and removed from office if found guilty.

In your view, should the president be impeached and removed for such behavior or should be immune during his or her presidency?

Be impeached and removed.

- Enjoy immunity

\section{Appendix B}

Support for norm erosion correlated with threat perceptions and with partisan social identity (in-party in power condition)

\begin{tabular}{|c|c|c|c|c|c|c|}
\hline & -1 & -2 & -3 & -4 & -5 & -6 \\
\hline VARIABLES & $\begin{array}{c}\text { Norm Erosion } \\
\text { All }\end{array}$ & $\begin{array}{c}\text { Norm Erosion } \\
\text { Democrats }\end{array}$ & $\begin{array}{c}\text { Norm Erosion } \\
\text { Republicans }\end{array}$ & $\begin{array}{c}\text { Norm Erosion } \\
\text { All }\end{array}$ & $\begin{array}{c}\text { Norm Erosion } \\
\text { Democrats }\end{array}$ & $\begin{array}{c}\text { Norm Erosion } \\
\text { Republicans }\end{array}$ \\
\hline $\begin{array}{l}\text { Out-group } \\
\text { Threat }\end{array}$ & $-0.1 * * *$ & $-0.2 * * *$ & $0.1^{* * *}$ & & & \\
\hline & {$[0.0]$} & {$[0.0]$} & {$[0.0]$} & & & \\
\hline $\begin{array}{l}\text { Partisan Social } \\
\text { Identity }\end{array}$ & & & & $0.2 * * *$ & $0.1 * * *$ & $0.3 * * *$ \\
\hline & & & & {$[0.0]$} & {$[0.0]$} & {$[0.0]$} \\
\hline Constant & $38.6^{* * *}$ & $44.4^{* * *}$ & $32.6^{* * *}$ & $20.5^{* * *}$ & $21.0 * * *$ & $20.6^{* * *}$ \\
\hline & {$[1.8]$} & {$[2.3]$} & {$[2.6]$} & {$[1.5]$} & {$[2.0]$} & [2.1] \\
\hline Observations & 1,484 & 839 & 645 & 1,481 & 838 & 643 \\
\hline R-squared & 0.006 & 0.059 & 0.015 & 0.053 & 0.018 & 0.139 \\
\hline
\end{tabular}


